\title{
Initial Study on the Guava Aroma of Chenin Blanc and Colombar Wines
}

\author{
C. S. DU PLESSIS and O. P. H. AUGUSTYN \\ Oenological and Viticultural Research Institute, Private Bag X5026, STELLENBOSCH, 7600
}

\begin{abstract}
An initial study indicated the importance of mercaptan on the aroma of Colombar and Chenin blanc wines. A synthesized mercaptan viz. 4-methyl-4-mercapto-pentan-2-one when added to neutral wine effected a Colombar or Chenin blanc wine aroma. The importance of sulphur components on wine aroma is emphasized.
\end{abstract}

Chenin blanc and Colombar wines in South Africa often have an aroma which is likened to that of the guava fruit. In a recent study on the "ribes" off-flavour in beer, Cosser, Murray \& Holzapfel (1980) noted that the "ribes" flavour in high dilution resembled the flavour of guavas. It was surmised that the cause of the "ribes" flavour in beer and that of the "guava" flavour in Chenin blanc and Colombar wines could be the same or related chemical compound(s). Cosser, et al. (1980) identified the component responsible for the "ribes" flavour to be a mercaptan viz. 4-methyl-4-mercapto-pentan-2-one. A preliminary study was undertaken to determine whether sulphur compounds as a group, mercaptans as a group or the "ribes" mercaptan contributed towards the guava flavour of Chenin blanc and Colombar wines.

\section{MATERIALS AND METHODS}

The chemical odour filter technique of Brenner, Owades \& Fazio (1955) was applied to differentiate between sulphides and mercaptans as the compounds possibly responsible for the strong guava flavour of a commercial Colombar wine.

The 4-methyl-4-mercapto-pentan-2-one (MMP) was synthesized as described by Pearce, et al. (1967). Thirty microliters of the reaction product (without purification of the mercaptan) was added to $750 \mathrm{~cm}^{3}$ of a white wine selected for its neutral aromatic character and absence of any guava-like flavours. This treated base wine was further diluted 500-fold with the untreated neutral wine and its aroma subsequently compared with that of the untreated wine.

Paired difference tests were used to determine whether mercaptans as a group or MMP specifically contributed towards the guava-like aroma. In these tests judges were asked to indicate the sample with the strongest cultivar aroma, name the cultivar and to comment on its aroma.

Triangle tests were used to determine whether sulphides as a group contributed to the guava aroma and also to ascertain whether the added MMP could be identified significantly as being a foreign flavour in wine. Judges were asked to identify the odd sample, specify the reason for their choice, name the cultivar and to comment on the nature of the aroma. Statistical significance of differences were determined from the tables of Roessler, et al. (1978).

\section{RESULTS AND DISCUSSION}

The addition of cadmium sulphate used by Brenner $e t$ al. (1955) to form non-volatile odourless sulphides, did not affect the aroma of the "guava-like" Colombar wine (Table 1), and it could be concluded that sulphides did not contribute towards the guava-like aroma of the wine.

TABLE 1

Triangle sensory test of Colombar wine to identify sample which had received cadmium sulphate*

\begin{tabular}{|c|c|c|c|c|}
\hline \multirow{2}{*}{ Judges } & \multicolumn{3}{|c|}{ Odd sample } & \multirow{2}{*}{ Cultivar } \\
\hline & 1 & $2^{*}$ & 3 & \\
\hline $1 \ldots \ldots \ldots \ldots \ldots$ & - & - & + & Chenin blanc \\
\hline $2 \ldots \ldots \ldots \ldots \ldots$ & - & + & - & Chenin blanc \\
\hline $3 \ldots \ldots \ldots \ldots$ & + & - & - & \\
\hline $4 \ldots \ldots \ldots \ldots$ & - & - & + & Colombar \\
\hline $5 \ldots \ldots \ldots \ldots$ & - & + & - & Chenin blanc \\
\hline $6 \ldots \ldots \ldots \ldots \ldots$ & + & - & - & \\
\hline $7 \ldots \ldots \ldots \ldots$ & - & + & - & Colombar \\
\hline $8 \ldots \ldots \ldots \ldots$ & + & - & - & \\
\hline $9 \ldots \ldots \ldots \ldots$ & - & + & - & Chenin blanc \\
\hline $10 \ldots \ldots \ldots \ldots$ & - & - & + & Chenin blanc \\
\hline $11 \ldots \ldots \ldots \ldots$ & - & - & + & \\
\hline $12 \ldots \ldots \ldots \ldots$ & - & + & - & Chenin blanc \\
\hline
\end{tabular}

*5 $\mathrm{m} \ell 5 \%$ cadmium sulphate solution added to sample 2 . Samples 1 and 3 received $5 \mathrm{~m} \ell$ distilled water each.

+Sample marked as odd by judge.

When copper sulphate was added to the wine to form non-volatile odourless mercaptans (Brenner et al. 1955) a highly significant decrease in guava aroma was obtained (Table 2).

TABLE 2

Paired-difference sensory test of Colombar wine to identify sample with strongest cultivar aroma

\begin{tabular}{|c|c|c|c|}
\hline \multirow{2}{*}{ Judges } & \multicolumn{2}{|c|}{ Strongest Cultivar Aroma } & \multirow{2}{*}{$\begin{array}{c}\text { Cultivar } \\
\text { identification }\end{array}$} \\
\hline & Copper Sulphate added* & No additions & \\
\hline $1 \ldots \ldots \ldots$ & - & + & Chenin blanc \\
\hline $2 \ldots \ldots \ldots$ & - & + & Chenin blanc \\
\hline $3 \ldots \ldots \ldots$ & - & + & \\
\hline $4 \ldots \ldots \ldots$ & - & + & $\begin{array}{l}\text { Chenin bland } \\
\text { Colombar }\end{array}$ \\
\hline $5 \ldots \ldots \ldots$ & - & + & Chenin blanc \\
\hline $6 \ldots \ldots \ldots$ & - & + & Chenin blanc \\
\hline $7 \ldots \ldots \ldots$ & - & + & Colombar \\
\hline $8 \ldots \ldots \ldots$ & - & + & \\
\hline $9 \ldots \ldots \ldots$ & - & + & Chenin blanc \\
\hline $10 \ldots \ldots$ & - & + & Chenin blanc \\
\hline $11 \ldots \ldots \ldots$ & + & - & \\
\hline $12 \ldots \ldots \ldots$ & - & + & Colombar \\
\hline
\end{tabular}

+ Strongest cultivar character indicated.

*Due to the blue colour of the copper sulphate solution opaque black tasting glasses were used.

${ }^{* *}$ Cultivar identified in sample with strongest cultivar aroma. 
The results obtained when MMP was added to a neutral wine are summarised in Tables 3 and 4 from which it is clear that a strong guava-like aroma was induced in the neutral wine. In the majority of cases the judges named the sample to which MMP was added as being either Chenin blanc or Colombar and noted the aroma to be "guava". In two instances the aroma was also described as being "sweaty" or "catty". All these terms have in the past been used by judges in describing the aroma of natural Chenin blanc and Colombar wines.

Although the synthesized MMP does bring about an aromatic characteristic in wine which is recognized as being similar to that of normal Chenin blanc or Colombar wines, there is insufficient evidence at this stage to accept that MMP as such is indeed the causal component in natural wines. Furthermore, MMP has not yet been found to occur naturally in wine. Clapperton, Dalgliesh \& Meilgaard (1976) reported that p-menthane-8-thiol-3one also has an odour of "ribes". Furthermore, Maarse \& Ten Noever de Brauw (1974) reported that the carbonyl group in MMP is apparently not essential for the aroma of this compound. It is, therefore, possible that the component contributing to the typical natural aroma of Chenin blanc or Colombar is not MMP. In future studies it will be important to identify the specific wine aroma component and as soon as this has been done, a meaningful study on origin, metabolic formation of the compound etc. can be undertaken.

This work has indicated the importance of sulphur compounds in wine aroma. In this instance, mercaptans, (present in low concentrations), which have in the past been associated with malodours, have been shown to contribute positively to wine aroma and consequently wine quality. In fact, it appears as if the positive contribution of sulphur components to the aromas of fruits has also not yet been recognized. The application of the chemical odour filter test to guava juice indicates that mercaptans are very important components to the guava flavour. Earlier work (Du Plessis \& Loubser, 1974; Loubser \& Du Plessis, 1977) showed the importance of another sulphur compound in wines on bottle bouquet and bears out that the organic sulphur compounds as a group should receive more attention in this regard.

TABLE 3

Sensory evaluation of neutral wine with added MMP in paired-difference test.

\begin{tabular}{|c|c|c|c|c|}
\hline \multirow{2}{*}{ Judges } & \multicolumn{2}{|c|}{ Strongest cultivar aroma } & \multirow{2}{*}{$\begin{array}{l}\text { Cultivar } \\
\text { identified as:- }\end{array}$} & \multirow{2}{*}{ Comments } \\
\hline & No additions & MMP added & & \\
\hline $1 \ldots \ldots \ldots \ldots \ldots \ldots$ & - & + & Chenin blanc & Guava \\
\hline $3 \ldots \ldots \ldots \ldots \ldots$ & - & + & Chenin blanc & Slightly sweaty \\
\hline $4 \ldots \ldots \ldots \ldots \ldots \ldots$ & - & + & Chenin blanc & Very strong aroma \\
\hline $5 \ldots \ldots \ldots \ldots \ldots$ & - & + & Chenin blanc & Fruity, green peach (guava) \\
\hline $6 \ldots \ldots \ldots \ldots \ldots$ & - & + & Chenin blanc & Over-ripe guava \\
\hline $8 \ldots \ldots \ldots \ldots \ldots \ldots$ & - & + & Chenin blanc & Fruity, guava \\
\hline $9 \ldots \ldots \ldots \ldots \ldots \ldots \ldots$ & - & + & - & Pleasant aroma \\
\hline $10 \ldots \ldots \ldots \ldots \ldots$ & - & + & Chenin blanc & Very strong guava aroma \\
\hline $11 \ldots \ldots \ldots \ldots \ldots \ldots$ & - & + & Chenin blanc & Character occurring in Chenin blanc and Colombar \\
\hline $12 \ldots \ldots \ldots \ldots \ldots \ldots$ & - & + & Chenin blanc & Sweaty \\
\hline $13 \ldots \ldots \ldots \ldots \ldots$ & - & + & Chenin blanc & Prominent guava \\
\hline $14 \ldots \ldots \ldots \ldots \ldots$ & - & + & Chenin blanc & Catty \\
\hline
\end{tabular}

MMP: 4-Methyl-4-mercapto-pentan-2-one in reaction mixture; $0,08 \mu \ell /$ litre wine

TABLE 4

Identification of sample with added MMP in triangle sensory evaluation test

\begin{tabular}{|c|c|c|c|c|c|}
\hline \multirow{2}{*}{ Judges } & \multicolumn{3}{|c|}{ Samples } & \multirow{2}{*}{$\begin{array}{c}\text { Cultivar } \\
\text { identified as:- }\end{array}$} & \multirow{2}{*}{ Comments } \\
\hline & No addition & MMP added & No addition & & \\
\hline $1 \ldots \ldots \ldots \ldots \ldots \ldots$ & - & + & - & Colombar & Guava, slightly catty \\
\hline$\ldots \ldots \ldots \ldots \ldots$ & - & - & + & Chenin blanc & $\overline{0}$ \\
\hline $3 \ldots \ldots \ldots \ldots \ldots \ldots$ & - & + & - & Chenin blanc & Over-ripe fruit \\
\hline $4 \ldots \ldots \ldots \ldots \ldots \ldots$ & - & + & - & - & Overwhelming \\
\hline $5 \ldots \ldots \ldots \ldots \ldots \ldots$ & - & + & - & - & Fruity, green peach (guava) \\
\hline $6 \ldots \ldots \ldots \ldots \ldots \ldots$ & - & + & - & - & Guava, over-ripe \\
\hline $7 \ldots \ldots \ldots \ldots \ldots \ldots$ & - & + & - & Chenin blanc & - \\
\hline $8 \ldots \ldots \ldots \ldots \ldots$ & - & + & - & Chenin blanc & Fruity, guava \\
\hline $9 \ldots \ldots \ldots \ldots \ldots \ldots$ & - & + & - & - & Pleasant aroma \\
\hline $10 \ldots \ldots \ldots \ldots \ldots \ldots$ & - & + & - & Chenin blanc & Very strong guava \\
\hline $11 \ldots \ldots \ldots \ldots \ldots$ & - & + & - & - & Not specifically related to cultivar \\
\hline $12 \ldots \ldots \ldots \ldots \ldots \ldots$ & - & + & - & Chenin blanc & Pleasant guava \\
\hline $13 \ldots \ldots \ldots \ldots \ldots$ & - & + & - & Chenin blanc & Prominent guava \\
\hline $14 \ldots \ldots \ldots \ldots \ldots \ldots$ & - & + & - & Chenin blanc & Slightly catty \\
\hline
\end{tabular}

MMP: See footnote Table 3. 


\section{LITERATURE CITED}

BRENNER, M. W., OWADES, J. L. \& FAZIO, T. 1955. Determination of volatile sulphur compounds IV. Further notes on mercaptans. Proc. Am. Soc. Brew. Chemists. $125-132$.

ClAPPERTON, J. F., DALGLIESH, C. E. \& MEILGAARD, M. C. 1976. Progress towards an international system of beer flavour terminology. J. Inst. Brew. 82, 7-13.

COSSER, K. B., MURRAY, J. P. \& HOLZAPFEL, C. W. 1980. Investigation of a ribes off-flavour in beer MBAA. $17,53-59$.

DU PLESSIS, C. S. \& LOUBSER, G. J. 1974. The bouquet of "late harvest" wine. Agrochem. 6, 49-52.
LOUBSER, G. J. \& DU PLESSIS, C. S. 1977. The quantitative determination and some values of dimethyl sulphide in white table wines. Vitis. 15, 248-252.

MAARSE, H. \& TEN NOEVER DE BRAUW, M. C. 1974. Another catty odour compound causing air pollution. Chemy. Ind. 36-37.

PEARCE, J. T. P., PEACOCK, J. M., AYLWARD, F. \& HAISMAN, D. R. 1967. Catty odours in food: Reactions between hydrogen sulphide and unsaturated ketones. Chemy. Ind. 1562-1563.

ROESSLER, E. B., PANGBORN, R. M., SIDEL, J. L. \& STONE, H. 1978. Expanded statistical tables for estimating significance in paired-preference, paired-difference, duotrio and triangle tests. J. Food Sci. 43, 940-943, 947. 